\title{
Haematological and biochemical abnormalities in hunting dogs infected with Acanthocheilonema reconditum, associated risk factors, and a European overview
}

\author{
Laura Pacifico ${ }^{1}$. Nicola Ferrari ${ }^{2}$. Claudia Romeo ${ }^{2}$ - Francesco Buono ${ }^{1}$. Paolo Varuzza ${ }^{1} \cdot$ Giovanni Sgroi $^{1,3}$. \\ Benedetto Neola ${ }^{1}$. Jesse Buch ${ }^{4} \cdot$ Melissa Beall $^{4}$ - Edward B. Breitschwerdt ${ }^{5} \cdot$ Ramaswamy Chandrashekar $^{4}$. \\ Vincenzo Veneziano ${ }^{1,6}$ (D) $\cdot$ Diego Piantedosi ${ }^{1}$
}

Received: 25 January 2021 / Accepted: 29 April 2021 / Published online: 8 May 2021

(C) The Author(s) 2021

\begin{abstract}
Acanthocheilonema reconditum is a filarial parasite transmitted by arthropods (fleas, lice, and ticks) that infect dogs. There is minimal published data available to date on potential haematological and biochemical changes associated with this parasitic infection. Study aims were (i) provide an overview of $A$. reconditum in Europe, (ii) define A. reconditum prevalence and risk factors in a specific dog population (hunting) from southern Italy, and (iii) assess the frequency of haemato-biochemical abnormalities associated with infection. Blood samples collected from 3020 dogs were tested by a modified Knott's technique to count and identify microfilariae. Eighty-four dogs were infected by A. reconditum $(2.78 \%$; 95\% CI 2.19-3.37\%). Microfilariae ranged from 1 to $212 / \mathrm{ml}$. Based on clinical examination, all but six dogs with non-specific symptoms were healthy. Haematological abnormalities included leucocytosis $(n=15)$, with eosinophilia $(n=14)$ and monocytosis $(n=13)$. Serum biochemical abnormalities included increased total serum proteins $(n=19)$, albumins $(n=7)$, total globulins $(n=14)$, ALT $(n=$ 1 ), and ALP $(n=1)$; one dog was hypoalbuminemic, and BUN was mildly increased in 2 dogs. Risk factors included the province origin (Napoli, OR=5.4, 95\%CI: 2.1-14.0; Caserta, OR=5.1, 95\%CI: 2.5-10.6), hunting wild mammals (OR=2.8, 95\% 95\%CI: 1.6-4.8), and ectoparasite infestation ( $\mathrm{OR}=1.9,95 \% \mathrm{CI}$ : 1.1-3.1). There was a negative correlation between microfilaraemic load and decreased albumin level $(-0.37 ; p=0.021)$. Our results showed that $A$. reconditum circulates within the hunting dog population of southern Italy, with seemingly low pathogenic potential.
\end{abstract}

Keywords Filarial nematodes $\cdot$ Acanthocheilonema spp. $\cdot$ CVBDs $\cdot$ Hunting dogs

Section Editor: Abdul Jabbar

Vincenzo Veneziano

vinvene@unina.it

1 Department of Veterinary Medicine and Animal Productions, Università degli Studi di Napoli "Federico II", Via F. Delpino 1, 80137 Naples, Italy

2 Department of Veterinary Medicine, Università degli Studi di Milano, Via Celoria 10, 20133 Milan, Italy

3 Department of Veterinary Medicine, University of Bari Aldo Moro, Valenzano, Bari, Italy

4 IDEXX Laboratories, Inc., Westbrook, ME 04092, USA

5 Department of Clinical Sciences, College of Veterinary Medicine, North Carolina State University, Raleigh, NC 27607, USA

6 Osservatorio Faunistico Venatorio - Regione Campania, Naples, Italy

\section{Introduction}

Canine vector-borne diseases (CVBDs) are of historical and growing concern in veterinary and human medicine, and among these, particular interest is focused on the spread, diagnosis, and control of filarial worms (Otranto et al. 2013; Capelli et al. 2018; Genchi and Kramer 2020). Filarial nematodes reported in dogs include Dirofilaria immitis, Dirofilaria repens, Acanthocheilonema reconditum (syn. Dipetalonema reconditum), Acanthocheilonema dracunculoides, whose microfilariae parasitize the blood, and Cercopithifilaria grassi, Cercopithifilaria bainae, Cercopithifilaria sp. II sensu Otranto et al. 2012, and Onchocerca lupi, whose larval forms localize within the subcutaneous tissue (Ramos et al. 2016). Due to their pathogenic potential, D. immitis and D. repens represent the most well-studied species, while knowledge about other filarial nematodes such as A. reconditum is 
considerably less well characterized (Dantas-Torres and Otranto 2020; Genchi and Kramer 2020; Panarese et al. 2020).

Acanthocheilonema reconditum (syn. Dipetalonema reconditum) parasitizes domestic and wild canids, such as foxes (Marconcini et al. 1996; Ionică et al. 2017; Otranto et al. 2019). Reported intermediate hosts include fleas (Ctenocephalides canis, Ctenocephalides felis, Pulex irritans, Pulex simulans, Echidnophaga gallinae), lice (Heterodoxus spiniger, Linognathus setosus), and ticks (Rhipicephalus sanguineus) (Cringoli et al. 2001; Brianti et al. 2012; Napoli et al. 2014). Acanthocheilonema reconditum is widespread and its presence has been reported in Asia, Africa, America, Oceania, and Europe, localized mainly in the Mediterranean area (Otranto et al. 2013); furthermore, it is reported historically as the most common filaroid species in southern Italy, as well as D. repens (Mendoza-Roldan et al. 2020).

Acanthocheilonema reconditum is commonly considered an apathogenic parasite, as most studies do not describe clinical disease associated with confirmed infection (Pantchev et al. 2011; Brianti et al. 2012; Otranto et al. 2013). In addition, Papazahariadou et al. (1994) reported no correlation between episodic weakness in hunting dogs and A. reconditum infection. In contrast, a purulent mesenteric lymphadenitis was reported by Lindemann et al. (1983) as acute response in an experimentally infected dog. Martins Pereira et al. (2004) also described two erratic migrations and ectopic localizations of adult worms, with one dog having adult parasites in the heart (left ventricle), in association with bronchopneumonia and microfilariae in the alveoli, and the other with adult worms in the ovarian large ligament, occasionally found during ovariectomy. Other sporadic clinical abnormalities related with A. reconditum infection included subcutaneous suppurative inflammatory nodules in a naturally infected dog (Engelmann et al. 2019). Regarding clinical pathology, few reports have considered the occurrence of haematological and biochemical abnormalities in A. reconditum-infected dogs. A peripheral eosinophilia was found in experimentally infected dogs in the acute/invasive phase, while lymphocytosis developed during the chronic phase of infection (Lindemann et al. 1983). In one study involving naturally infected dogs, Hashem and Badawy (2007) reported regenerative hypochromic anaemia, leucocytosis with neutrophilia, eosinophilia and monocytosis, increased serum liver enzymes (aspartate aminotransferase-AST, alanine aminotransferase-ALT and total bilirubin), and renal function parameters (blood urea nitrogen-BUN, creatinine, and serum inorganic phosphate).

Hunting dogs are frequently exposed to vector-borne pathogens due to their lifestyle, which is characterized by closer contact with wooded areas, cohabitation in outdoor kennels, and potentially less consistent use of antiparasitic drugs with limited care provided by owners (Piantedosi et al. 2017; Orr et al. 2020). Moreover, intense physical activity makes hunting dogs more susceptible to episodic weakness, as often reported by hunters. Diagnostic evaluation of episodic weakness can be challenging, and a previous study associated the presence of filariasis with exercise intolerance (Papazahariadou et al. 1994). While the pathogenesis of $D$. immitis microfilariae is well known, minimal data regarding the pathogenic potential role of $A$. reconditum microfilariae are available (McCall et al. 2008; Muñoz-Caro et al. 2018).

Based on the above premises, the aims of the present study were (i) to illustrate the distribution and the epidemiology of A. reconditum infection in dogs in Europe, (ii) to assess the prevalence and risk factors of $A$. reconditum infection in a large and specific hunting $\operatorname{dog}$ population from southern Italy, and (iii) to determine the frequency of haematological and serum biochemical abnormalities associated to A. reconditum infection as related to the microfilariae load.

\section{Overview of Acanthocheilonema reconditum epidemiology in dogs in Europe}

Acanthocheilonema reconditum (syn. Dipetalonema) was first described by Grassi in 1889. Grassi and Calandruccio (1890) defined morphological differences with $D$. immitis, by reporting details on an immature female worm; the same authors proved that A. reconditum develops in fleas. Additional data was reported by Noë (1907), who described further morphological features, analyzing some adult specimens (male and female) of A. reconditum. Additional morphological characteristic of $A$. reconditum microfilariae was subsequently reported by Newton and Wright (1956). Subsequent studies further defined the life cycle and completed the description of the parasite's morphology (Newton and Wright 1956; Nelson 1962; Bain and Beaucournu 1974; Korkejian and Edeson 1978). Acanthocheilonema reconditum infections are reported in several European countries, and this worm is considered the main filaroid species infecting dogs in the Mediterranean basin (Brianti et al. 2012). Otranto et al. (2013) reported the geographical distribution of A. reconditum, showing its presence in Italy, Spain, Germany, Austria, and Greece. In another recent review, Tahir et al. (2019) described Acanthocheilonema infections (A. reconditum and A. dracunculoides), reporting the distribution in dogs and foxes in the Mediterranean basin, including the Middle East and northern Africa.

Full information about the prevalence of this parasite in dogs in Europe is scarce; most often its occurrence is a secondary finding within epidemiological surveys focused on other major Filaridae, such as D. immitis or D. repens.

In Italy, the presence of $A$. reconditum has been confirmed by different surveys in southern areas of the country (mean prevalence $7.7 \%$ ) (Cringoli et al. 2001; Veneziano 2001; Giannetto et al. 2007; Brianti et al. 2012). In northern and central regions of Italy, a lower prevalence was reported 
(mean prevalence $1 \%$ ) (Veneziano 2001; Magi et al. 2012; Gizzarelli et al. 2019; Macchioni et al. 2020), but in contrast, a higher infection rate $(7.7 \%)$ was described in Liguria region by Magi et al. (2016). Two recent countrywide Italian surveys reported an overall $A$. reconditum prevalence of $0.8 \%$ and 0.1\% (Brianti 2018, Traversa et al. 2019).

Among the other Mediterranean basin countries, presence of A. reconditum has been described in Greece, Cyprus, Turkey, Spain, Portugal, and France. In Greece, most studies are from the northern area of the country with a mean prevalence of 2.4 $\%$ (Papazahariadou et al. 1994; Founta et al. 1999; Diakou et al. 2016). In Cyprus, A. reconditum was the most represented among microfilaria species (Attipa et al. 2019; Kokkinos et al. 2019). In Turkey, Toparlak et al. (2005) showed A. reconditum as the only microfilaria species with a low prevalence $(0.6 \%)$ compared to the other Mediterranean countries. In Spain, a mean prevalence of $1.3 \%$ was reported (Perez-Sanchez et al. 1989; Ortega-Mora et al. 1991; Aranda et al. 1998), with hotspots in a central-northern area of the country (Soria province-15.8\%) and in the Canary Islands (20\%) (Ortega-Mora et al. 1991) In the Iberian Peninsula, Portugal showed a lower prevalence, with a mean value of $0.55 \%$ (Menn et al. 2010; Maia et al. 2016; Ferreira et al. 2017).

In France, the presence of $A$. reconditum was reported in different vector and life cycle studies, which contributed to the definitive classification of filarial species (Bain and Beaucournu 1974; Chauve 1990; Chabaud and Bain 1994). A very low prevalence $(0.05 \%)$ was reported by Ducos de Lahitte in 1990. Despite several studies about filariosis, to the best of our knowledge, there are no recently published data on the prevalence of $A$. reconditum in France, except for a 2019 survey reporting negative results for A. reconditum infection (Laidoudi et al. 2019).

Regarding countries of central Europe, in Switzerland, Belgium, and the Netherlands, despite the ascertained presence of other filarial species, A. reconditum seems never to have been reported (Meyer et al. 1994; Deplazes et al. 1995; Bucklar et al. 1998; Petruschke et al. 2001; Overgaauw and van Dijk 2009; De Bosschere and Kindermans 2019).

Several studies involving $A$. reconditum have been carried out in Germany with most of the infections described in imported dogs (Zahler et al. 1997; Pantchev et al. 2011; Hamel et al. 2012; Schäfer et al. 2019), but only few autochthonous cases were reported in central Germany $(0.19 \%)$ (Liesner et al. 2016).

In Austria, a single A. reconditum imported case was documented (Hinaidy et al. 1987), but no autochthonous infections were described (Prosl et al. 2003; Duscher et al. 2009).

In the UK, there is only one dated study describing A. reconditum microfilariae in imported dogs from Ireland (Jacobs and Prole 1976).

In the Balkanian area, the presence of A. reconditum was described in the northern region of Serbia (2.1\%) (Tasić et al.
2008), although two subsequent studies in the same country found negative results (Tasić et al. 2012; Potkonjak et al. 2020). In Slovenia, Croatia, and Bulgaria, A. reconditum microfilaraemia was not detected in surveys on filariosis in dogs (Kirkova et al. 2007; Georgieva et al. 2001; Morchón et al. 2012; Holler et al. 2010; Radev et al. 2016).

In the eastern European countries, A. reconditum was reported in Romania (2.05\%) (Ionică et al. 2015), while in Slovakia, the parasite was not found (Miterpáková et al. 2010; Víchová et al. 2014). In Poland, A. reconditum was reported in 2011, when two dogs were found positive during a survey on other filarial species (Masny et al. 2011).

In Baltic countries, despite the high prevalence of D. repens (Alsarraf et al. 2021), A. reconditum infection was not reported (Kartashev et al. 2011; Sabūnas et al. 2019) (Table 1; Fig. 1).

\section{Materials and methods}

\section{Study area}

The study area included six different hunting districts (ATCs) in Campania and Basilicata regions of southern Italy. These are located in the provinces of Napoli $\left(40^{\circ} 50^{\prime} \mathrm{N}-14^{\circ} 15^{\prime} \mathrm{E}\right)$

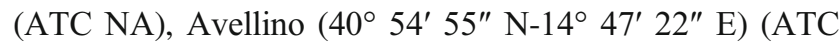
AV), Benevento $\left(41^{\circ} 08^{\prime} \mathrm{N}-14^{\circ} 47^{\prime} \mathrm{E}\right)$ (ATC BN), Caserta $\left(41^{\circ} 10^{\prime} \mathrm{N}-14^{\circ} 13^{\prime} \mathrm{E}\right)$ (ATC CE), Salerno $\left(40^{\circ} 41^{\prime} 00^{\prime \prime} \mathrm{N}-14^{\circ}\right.$ $47^{\prime} 00^{\prime \prime}$ E) (ATC SA1), and Potenza ( $40^{\circ} 38^{\prime} 19^{\prime \prime} \mathrm{N}-15^{\circ} 48^{\prime} 08^{\prime \prime}$ E) (ATC PZ). The territory of the Napoli, Caserta, Salerno, and Potenza provinces overlooks the Tyrrhenian Sea. The study region has a typical Mediterranean temperate climate along the coast, which becomes progressively continental in the inland and mountainous territories.

\section{Study animals and sample size}

The survey included 3020 hunting dogs and was performed in 81 private veterinary clinics located in the study area from 2014 to 2019; all procedures were performed for diagnostic purposes during a routine health check, and for this reason, the study did not require an ethical approval according to European Directive 2010/63/EU. Written informed consent was obtained from the owners of the hunting dogs included in the study.

The study was performed within a hunting dog's health assistance program of University of Naples, supported by the Italian management committees of the respective hunting districts (ATCs). In order to rule out the spread of major canine vector-borne pathogens in the study area, serological inclinic assay test systems [SNAP®4Dx®Plus (Ehrlichia canis, Anaplasma spp., Borrelia burgdorferi s.1., D. immitis)], based on enzyme immunoassay technique, were employed on each 


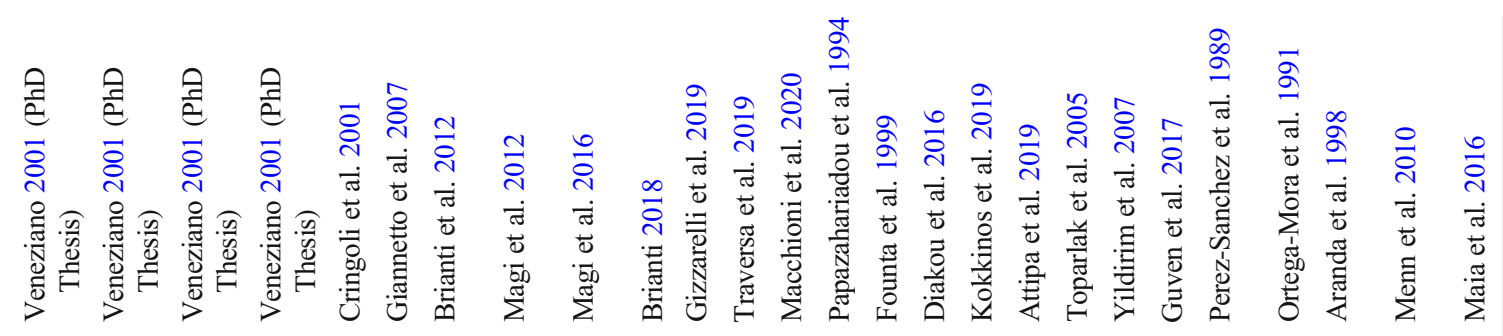

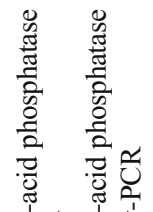

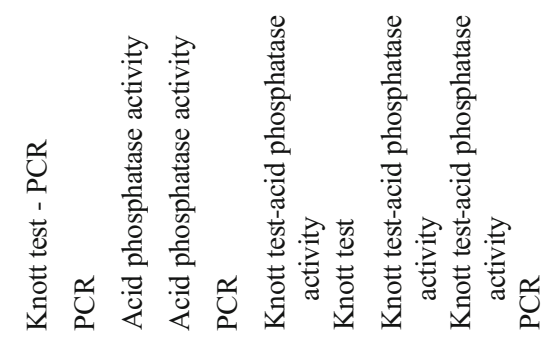

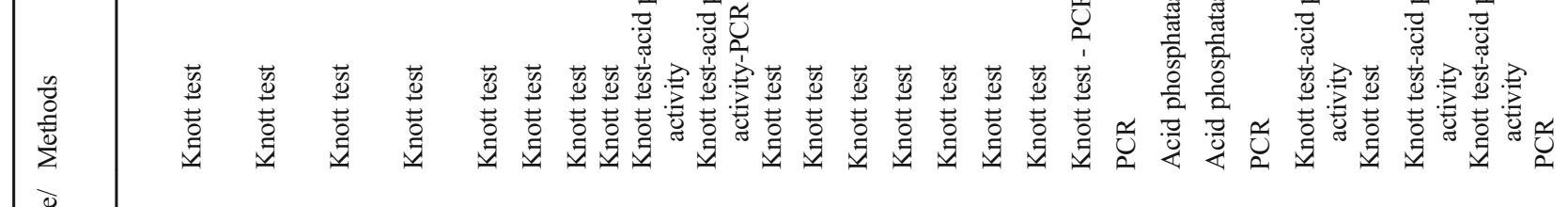

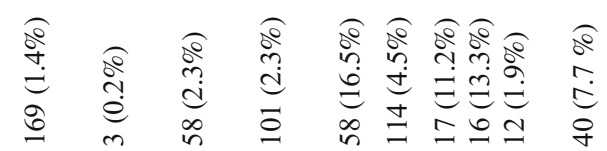

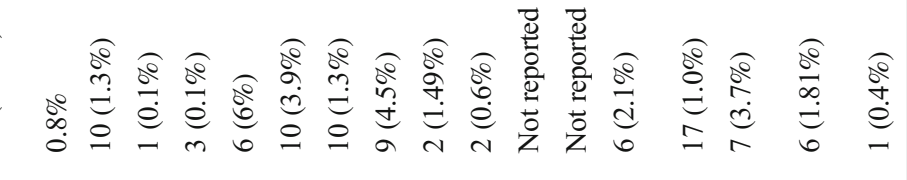

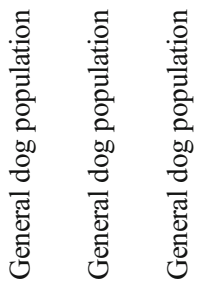
:

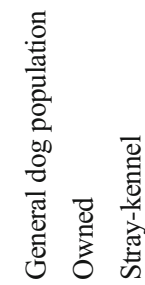

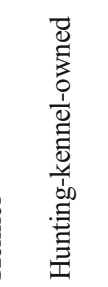

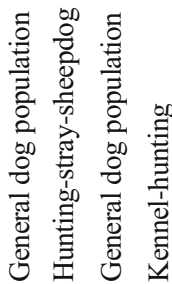

咅

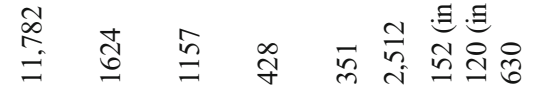
을
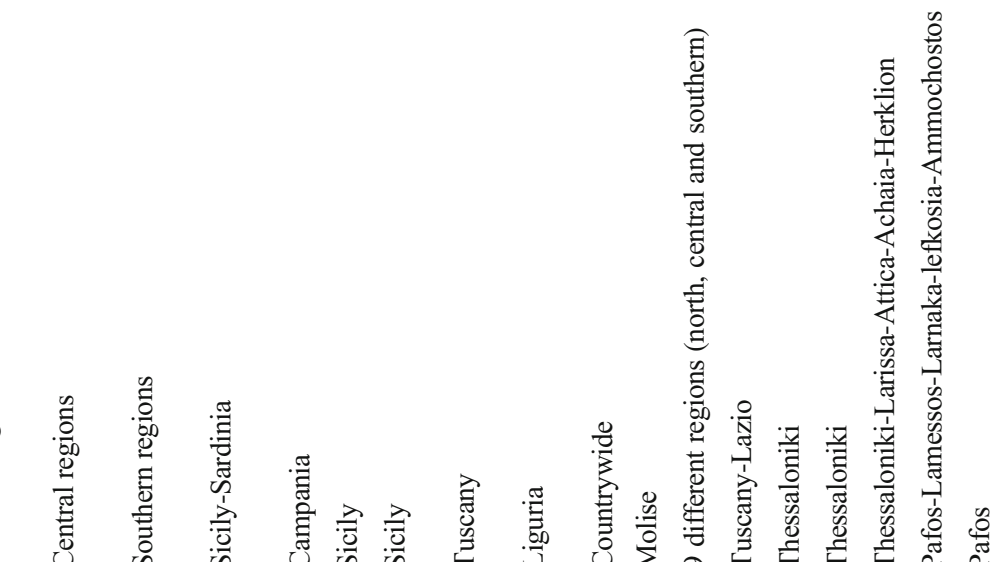

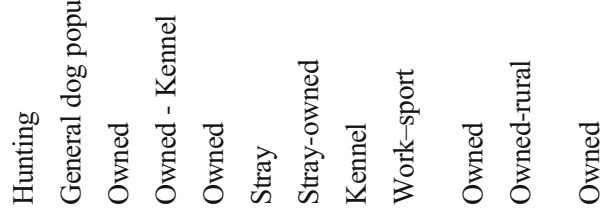

產<smiles>CC(C)C</smiles>
$\overrightarrow{\text { ल }}$ 总 莺 


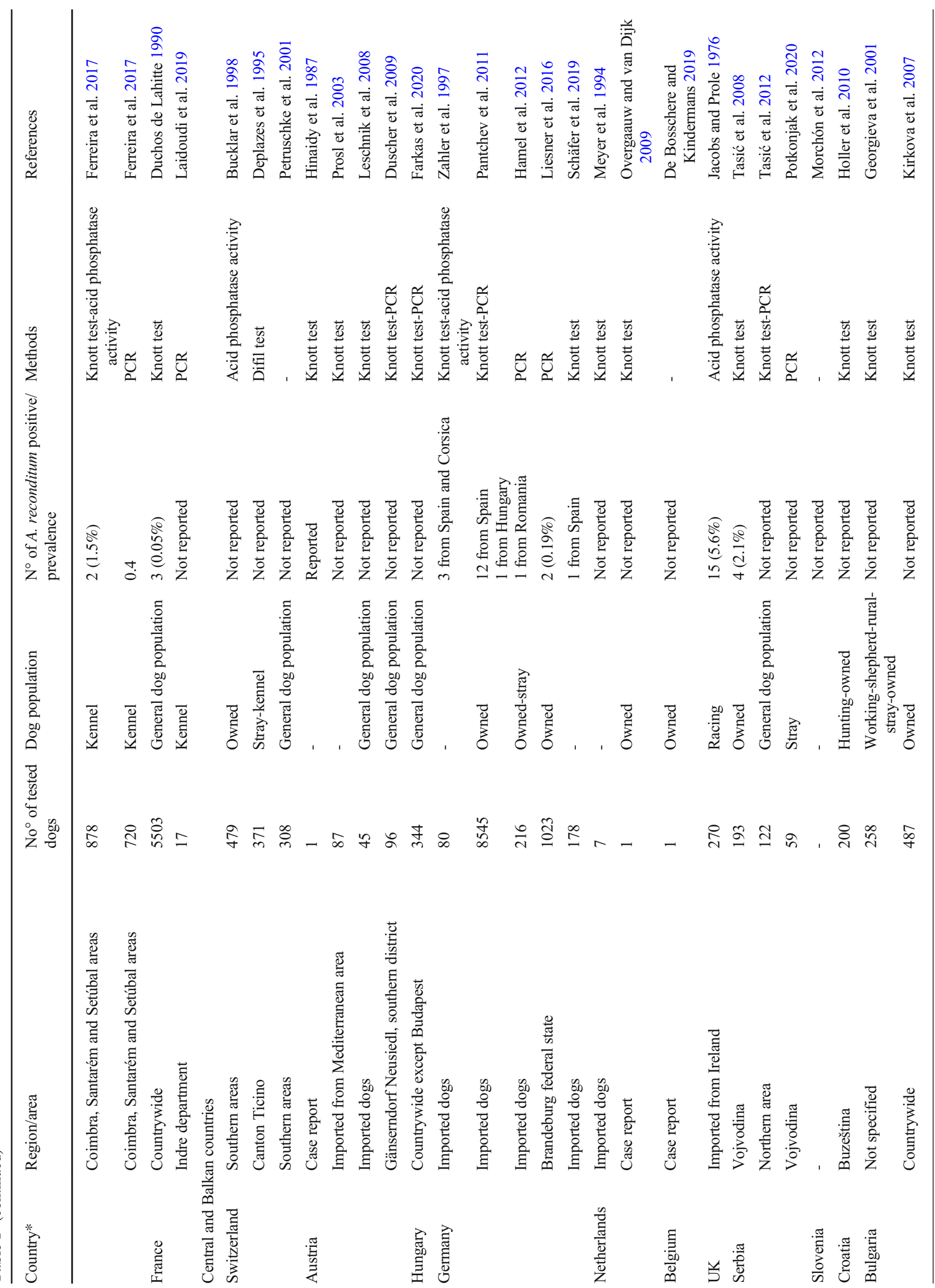


dog enrolled. Additionally, A. reconditum microfilaremic dogs were tested for antibodies to Leishmania infantum and for the presence of Angiostrongylus vasorum antigen, using the SNAP ${ }^{\circledR}$ Leishmania and IDEXX Angio Detect ${ }^{\circledR}$ Test kits, respectively, in order to rule out a possible coinfection with these two pathogens.

To better define $A$. reconditum infection risk, a questionnaire was administered to each owner to collect information about the dog's characteristics, habits, and management/ handling that might influence exposure and/or susceptibility to the parasite (see "Statistical analysis" for details). Because hunters from the Campania region have the habit of extralabel use of subcutaneous ivermectin injection for the prevention of ecto- and endoparasite infections (Piantedosi et al. 2017), owners were asked specifically in the questionnaire about macrocyclic lactone treatment schedule.

The necessary sample size to estimate prevalence of A. reconditum was calculated using the formula proposed by Thrusfield (1995), considering the following epidemiological data: expected prevalence of $16 \%$ based on the results of a similar study in no specific dog population from Campania region (southern Italy) (Cringoli et al. 2001); confidence interval (99\%) and desired absolute precision (2\%), based on the number of hunters in Campania region $\left(n^{\circ} 38,611\right.$ hunters in the season 2014-2015 and assuming one dog for each hunter) (BURC 2019).

\section{Sample collection}

For each dog, blood samples were obtained through percutaneous venipuncture of cephalic or jugular veins, after $12 \mathrm{~h}$ of fasting. The total amount of blood was immediately divided into three aliquots. The first two aliquots were placed in tubes containing potassium ethylene diamine tetra-acetic acid (EDTA) for complete blood count (CBC) and Knott test, which were carried out within $30 \mathrm{~min}$ of blood collection. The third aliquot was put in tubes without anticoagulant, allowed to clot and centrifuged at $908 \mathrm{~g}$ for $15 \mathrm{~min}$ at $4{ }^{\circ} \mathrm{C}$, in order to obtain blood serum samples that were stored at $-80^{\circ} \mathrm{C}$ and defrosted immediately before batch analyses of haematochemical parameters.

\section{Parasitological analysis}

For each dog involved in the study, the Knott's test technique (Knott, 1939) was carried out at the parasitology laboratories of the Department of Veterinary Medicine and Animal Productions, University Federico II, Naples, to find microfilariae in blood as follows: $1 \mathrm{ml}$ of whole blood was diluted with $9 \mathrm{ml}$ of $2 \%$ formalin in a centrifuge tube and after centrifugation for $10 \mathrm{~min}$ at $1500 \mathrm{rpm}$ the supernatant was discarded. Sediment sample $(20 \mu \mathrm{l})$ was transferred to a glass slide up to complete $1 \mathrm{ml}$ and examined using optical 
Fig. 1 Pooled prevalence (\%) of Acanthocheilonema reconditum in dogs within the European Union and adjacent countries at national level

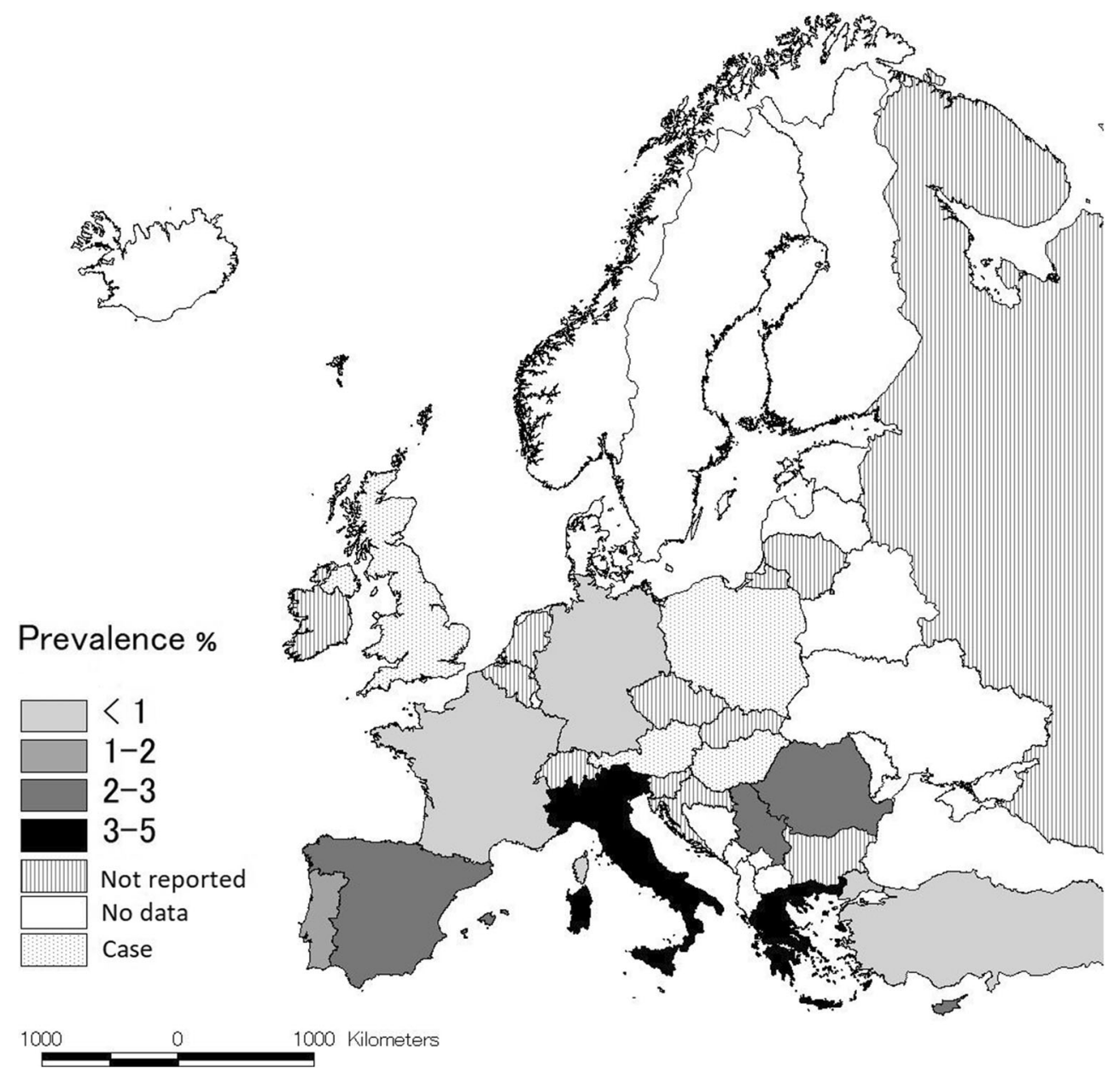

microscope at 10, 20,40, and $\times 100$ magnifications (Genchi et al. 2010).

In order to differentiate $A$. reconditum from other filarial species, blood microfilariae (D. repens, D. immitis, A. dracunculoides) were identified by morphological and morphometrical examinations. The diagnostic keys used to differentiate microfilariae species were morphology, shape of larval head and tail, and size measurements of length and width according to McCall et al. (2008). In addition, microfilariae were counted, and numbers were expressed as microfilariae/ml of blood ( $\mathrm{mf} / \mathrm{ml}$ blood). All the diagnostic procedures were performed with a LEICA DM 750 microscope (Germany) with digital camera; the image analysis system Leica Application Suite V 4.9 (LAS - ®Leica Microsystem) was used to get microfilariae measurements and take pictures.

\section{Clinical examination, complete blood count, and serum biochemistry}

A clinical examination was performed on each $A$. reconditum microfilaremic dog to evaluate the presence of systemic clinical signs such as fever, lymphadenomegaly, splenomegaly, changes in mucous membrane colour, cardiorespiratory abnormalities, skin lesions, and dehydration. The nutritional status was assessed using a nine-point body condition score (BCS) system (Laflamme 1997). A complete blood count (CBC) and a basic biochemical panel were obtained on each positive animal at the clinical pathology laboratories of the Department of Veterinary Medicine and Animal Productions, University Federico II, Naples.

Complete blood counts were performed on 32 microfilaremic dogs using a semi-automatic cell counter (HM5, Abaxis, USA). An automatic chemical chemistry analyzer (VetScan Vs2, Abaxis, USA) was used to measure concentrations or activities of blood urea nitrogen (BUN), creatinine, alanine aminotransferase (ALT), alkaline phosphate (ALP), total serum proteins (TP), albumins, and total globulins (TG) for 43 microfilaremic dogs.

\section{Statistical analysis}

Factors influencing the probability for dogs of being infected by $A$. reconditum were explored through a mixed effects logistic regression model with binary outcome. Ninety subjects were removed from the analysis due to missing information 
about one or more of the considered explanatory variables, for a final sample size of $2930 \mathrm{dogs}$. The effect on A. reconditum infection status (infected or uninfected) of the following variables extracted from the owners' questionnaire was examined: dog's age, gender, type of coat (short, medium, or long hair), living area (province) and environment (rural or urban), night shelter availability (yes or no), pack size, number of hunting months, type of hunted species (birds or wild mammals), travel abroad (yes or no), reported ectoparasite infestation history (yes or no), and ectoparasite treatment (yes or no). Owners' IDs were included in the model as a random factor, to account for potential covariance within packs. We first fitted a full, saturated model including all factors and obtained a minimal model through backward elimination of non-significant variables. Odds ratio (OR) estimates of the significant factors retained in the minimal model and their $95 \%$ confidence intervals (CIs) are presented.

For dogs with only A. reconditum infection, a Pearson's correlations was used to examine the association of the measured microfilarial load with the following haematological and biochemical variables: red blood cell count (RBC), haemoglobin concentration $(\mathrm{Hb})$, mean corpuscular haemoglobin $(\mathrm{MCH})$, mean corpuscular haemoglobin concentration (MCHC), white blood cell count (WBC) and percentage, absolute value of lymphocytes, neutrophils, eosinophils, and monocytes, and serum albumin level. All the analyses were carried out using SAS/STAT 9.4 software (Copyright $@ 2012$, SAS Institute Inc., Cary, NC, USA).

\section{Results}

Of the $3020 \mathrm{dogs}, 1660$ were males (55\%) and $1360(45 \%)$ females; average age was 3.8 years (min $0.25-\max 14)$. A total of 84 dogs were positive to A. reconditum at the Knott's test, with an overall prevalence of $2.8 \%$ (95\% CI: 2.19-3.37) (Fig. 2). A monospecific A. reconditum infection was detected in $71 \mathrm{dogs}$, whereas 4 dogs had mixed filarial infections ( 3 co-infected with $D$. repens and 1 with D. immitis); the remaining 9 dogs were co-infected with other vector-borne pathogens, prevalent in southern Italy (3 co-infected with Leishmania infantum; 3 co-infected with Ehrlichia canis and 3 co-infected with E. canis and Anaplasma spp., respectively).

Of the 71 dogs with only A. reconditum infection, 35 $(48.6 \%)$ were from Caserta, 12 (16.9\%) from Napoli, 12

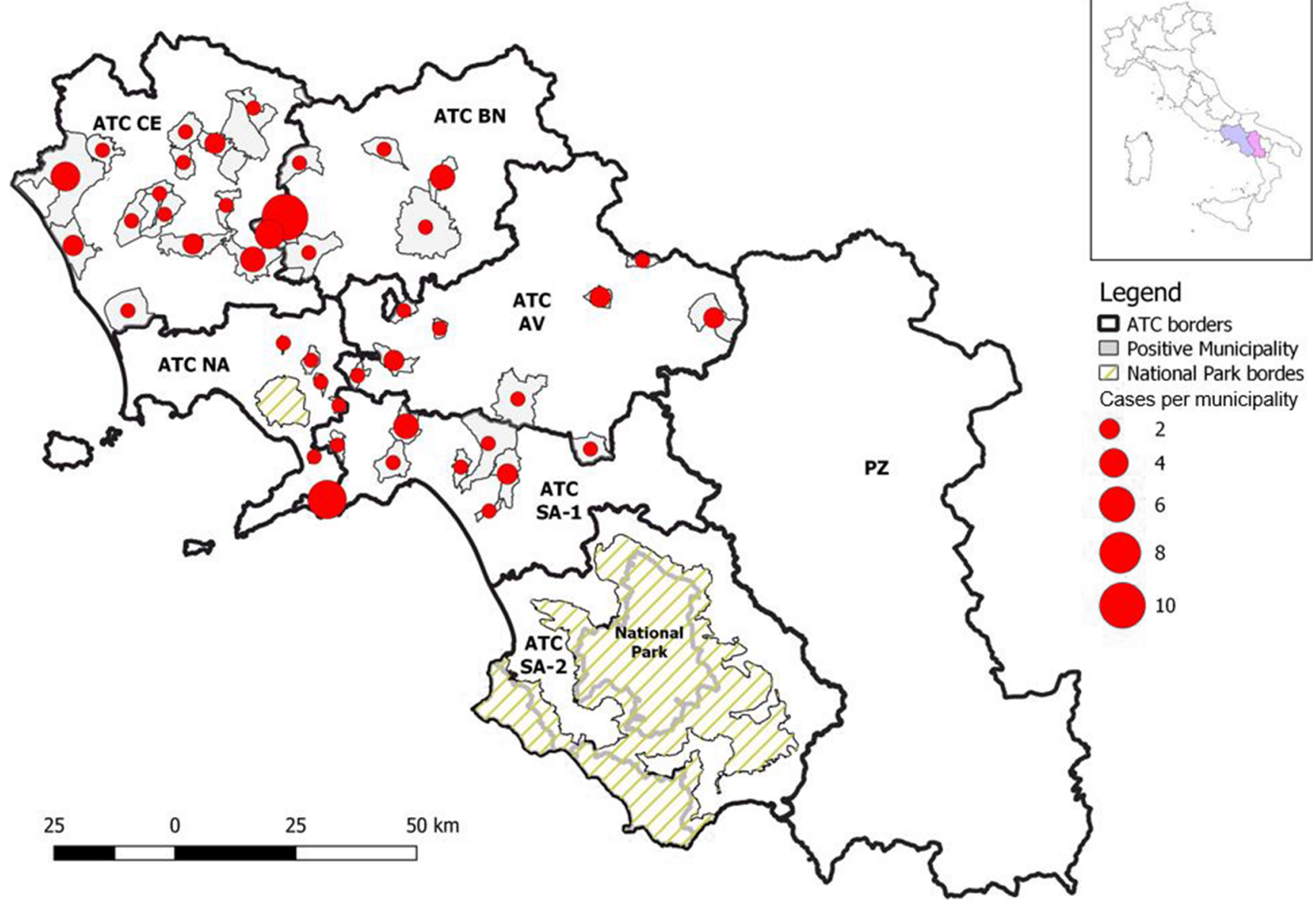

Fig. 2 Distribution map of Acanthocheilonema reconditum positive hunting dogs in the study area 
(16.9\%) from Avellino, 6 (8.5\%) from Benevento, and 6 $(8.5 \%)$ from Salerno province. No dogs from Potenza province had $A$. reconditum infection.

Based upon microscopic microfilariae counts, dogs were infected with an average \pm standard deviation (SD) of $29 \pm 36$ microfilariae/ml (min 1-max 212); the mean length was $265.7 \mu \mathrm{m} \pm 14.1$ and the mean width was $4.9 \mu \mathrm{m} \pm 0.5$ (Fig. 3).

During clinical examinations, the following clinical signs and laboratory abnormalities were reported in 71 A. reconditum single infection microfilaremic dogs: dehydration $(n=1)$, fever $(n=1)$, congested mucous membranes $(n=$ $1)$, weight loss (BCS 3$)(n=1)$, and exercise intolerance $(n=$ 2). $\mathrm{CBC}$ results revealed normocytic hypochromic anaemia (n $=1)$, thrombocytopenia $(n=7)$, thrombocytosis $(n=2)$, leukocytosis $(n=15)$, lymphocytosis $(n=4)$, lymphopenia $(n=$ 6), neutropenia ( $n=11)$, basophilia $(n=1)$, monocytosis $(n=$ $13)$, and eosinophilia $(n=14)$. Of the 7 thromobocytopenic dogs, 4 had platelet aggregation on microscopic blood smear examination. The serum biochemical abnormalities (serum values above the upper limit of the reference range) included increased total serum proteins $(n=19)$, albumins $(n=7)$, total globulins $(n=14)$, ALT $(n=1)$, and ALP $(n=1)$; one dog was hypoalbuminemic. Six dogs had BUN values below the reference range, and 2 dogs slightly above the reference interval. The mean value $( \pm \mathrm{SD})$ of haematological and biochemical data are resumed in Table 2 and Table 3.
Table 2 Mean value for complete blood count results in Acanthocheilonema reconditum microfilaremic dogs

\begin{tabular}{|c|c|c|c|}
\hline Parameter & Mean \pm SD & Min-max & Reference range* \\
\hline $\operatorname{RBC}\left(10^{12} / 1\right)$ & $6.4 \pm 0.69$ & $4-8.2$ & $5.5-8.5$ \\
\hline HCT (\%) & $43.6 \pm 4.56$ & $30.3-53.9$ & $37-55$ \\
\hline $\mathrm{Hb}(\mathrm{g} / \mathrm{dl})$ & $15.3 \pm 1.78$ & $9-18$ & $12-18$ \\
\hline MHC (pg) & $24.2 \pm 2.52$ & $17.6-30.8$ & $19.5-24.5$ \\
\hline $\operatorname{MCHC}(\mathrm{g} / \mathrm{dl})$ & $35.2 \pm 3.24$ & $28.3-46.4$ & $32-36$ \\
\hline $\mathrm{MCV}(\mathrm{fl})$ & $68.8 \pm 4.32$ & $60.9-78.4$ & $60-77$ \\
\hline PLT $\left(10^{9} / 1\right)$ & $290.2 \pm 156.23$ & $44-757$ & $200-500$ \\
\hline WBC $\left(10^{9} / 1\right)$ & $17.5 \pm 7.60$ & $8.5-44.9$ & $6-17$ \\
\hline $\mathrm{BA} \%$ & $0.9 \pm 0.78$ & $0-3$ & $0-2$ \\
\hline $\mathrm{EO} \%$ & $9.4 \pm 7.52$ & $0.3-32.3$ & $0-8$ \\
\hline LY\% & $19.8 \pm 9.01$ & $6-41.6$ & $12-30$ \\
\hline $\mathrm{MO} \%$ & $4.4 \pm 2.81$ & $0.5-10$ & $2-4$ \\
\hline NE\% & $64.5 \pm 11.03$ & $40.9-85.8$ & $62-87$ \\
\hline BA $\left(10^{9} / 1\right)$ & $0.2 \pm 0.17$ & $0-0.5$ & $0.0-0.4$ \\
\hline $\operatorname{EO}\left(10^{9} / 1\right)$ & $1.7 \pm 1.62$ & $0.1-6.5$ & $0.0-0.8$ \\
\hline $\operatorname{LY}\left(10^{9} / 1\right)$ & $3.3 \pm 1.74$ & $0.9-9.2$ & $1.0-4.8$ \\
\hline $\operatorname{MO}\left(10^{9} / 1\right)$ & $0.7 \pm 0.48$ & $0.1-1.9$ & $0.15-1.35$ \\
\hline $\mathrm{NE}\left(10^{9} / 1\right)$ & $11.6 \pm 6.39$ & $5.6-38.5$ & $3.0-12.0$ \\
\hline
\end{tabular}

*Internal laboratory reference values; $\operatorname{dogs} n=32$

Statistically, among the examined factors, only the dogs' living province $(p<0.0001)$, the type of hunted game

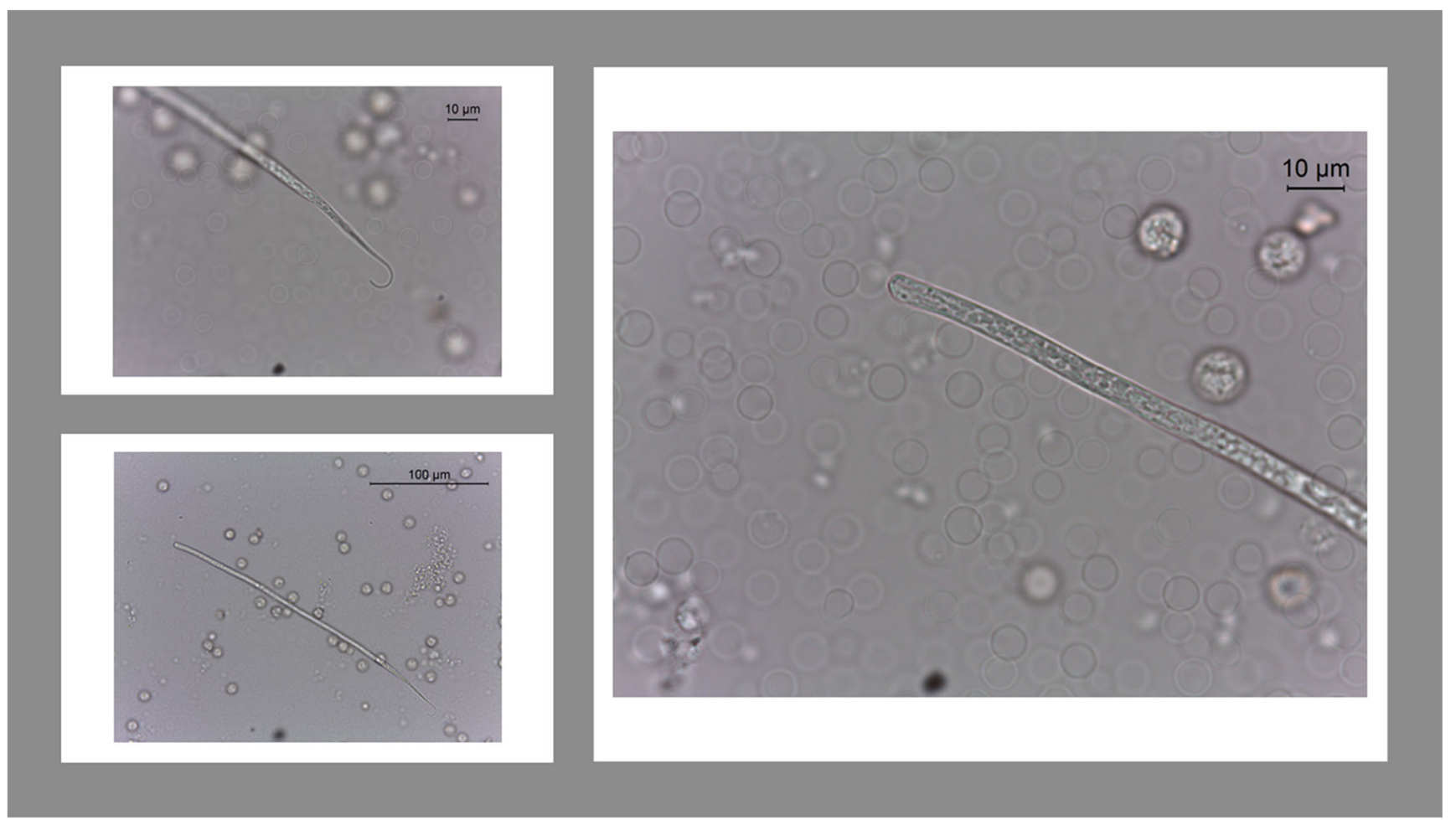

Fig. 3 Morphological details of Acanthocheilonema reconditum microfilariae isolated by the Knott test 
Table 3 Mean value for biochemical results in Acanthocheilonema reconditum microfilaremic dogs

\begin{tabular}{llll}
\hline Parameter & Mean \pm SD & Min-max & Reference range* \\
\hline BUN (mmol/l) & $3.93 \pm 1.68$ & $1.7-8.2$ & $2.5-7.2$ \\
Creatinine (umol/l) & $74.43 \pm 23.36$ & $18-130$ & $40-130$ \\
ALT (U/l) & $29.9 \pm 8.33$ & $10-47$ & $10-45$ \\
ALP (U/l) & $59.9 \pm 33.52$ & $21-173$ & $20-150$ \\
Serum total proteins (g/l) & $75.83 \pm 8.14$ & $58-94$ & $57-77$ \\
Albumins (g/l) & $34.12 \pm 5.78$ & $17-46$ & $25-40$ \\
Globulins (g/l) & $42 \pm 8.59$ & $28-67$ & $25-45$ \\
A/G ratio & $0.86 \pm 0.26$ & $0.30-1.4$ & $0.5-1.3$ \\
\hline
\end{tabular}

*Internal laboratory reference values; $\operatorname{dogs} n=43$

$(p=0.0002)$, and ectoparasite infestation history $(p=0.018)$ affected the probability of being $A$. reconditum infected (Table 4).

Specifically, living in Napoli (OR=5.4, 95\% CI: 2.1-14.0) and Caserta province (OR=5.1, 95\% CI: 2.5-10.6), wild mammals hunting (wild boars, hares, and foxes) (OR=2.8, 95\% CI: 1.6-4.8) and ectoparasite infestation history (ticks, fleas, and lice) (OR=1.9, 95\% CI: 1.1-3.1) represent risk factors for A. reconditum infection (Table 4; Figs. 4, 5, and 6).

Concerning the clinicopathological parameters, there was a significant negative correlation between microfilaremic load and the serum albumin levels (Pearson's correlation coefficient: $-0.37 ; p=0.021$ ) (Fig. 7). As the microfilariae number increased, the albumin level decreased linearly. For example, a dog with 100 microfilariae will have significantly lower albumin level than a dog with only microfilariae counts of two, despite the albumin value being within the laboratory reference range. There was no correlation with any other haematological or biochemical variable.

Table 4 Risk factors associated with Acanthocheilonema reconditum infection in hunting dogs from southern Italy $(n=2930)$

\begin{tabular}{llllll}
\hline Risk Factor & $\chi^{2}$ & Df & & OR & $95 \%$ CI \\
\hline Living province (ref: Salerno) & 35.0 & 5 & $<0.0001$ & & \\
Napoli & & & & 5.4 & $2.1-14.0$ \\
Caserta & & & & 5.1 & $2.5-10.6$ \\
Avellino & & & & 1.4 & $0.6-3.3$ \\
Benevento & & & & 1.1 & $0.4-2.9$ \\
Potenza & 14.3 & 1 & 0.0002 & & \\
Type of game (ref: Birds) & & & & 2.8 & $1.6-4.8$ \\
Mammals & 5.6 & 1 & 0.018 & & \\
Ectoparasite infestation (ref: No) & 5.9 & & & 1.9 & $1.1-3.1$ \\
Yes & & & & & \\
\hline
\end{tabular}

$\chi^{2}$ Chi square; $D f$ degree of freedom; $p$ p value; $O R$ odds ratio; $C I$ confidence interval

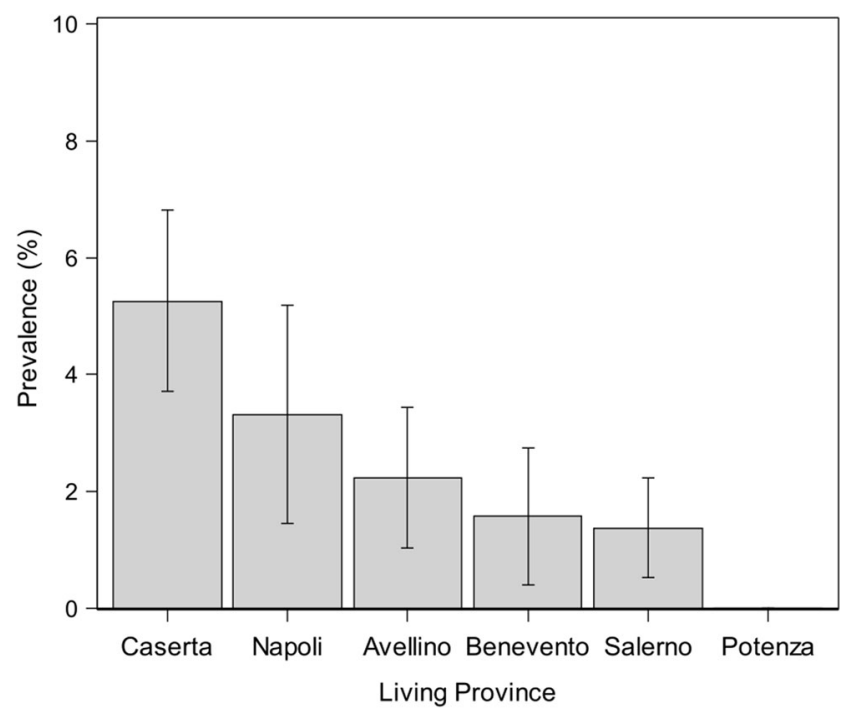

Fig. 4 Prevalence $( \pm \mathrm{SD})$ of Acanthocheilonema reconditum infection in hunting dogs from different provinces of Southern Italy

\section{Discussion}

Our study confirmed the presence of $A$. reconditum in hunting dogs living in Campania region of southern Italy. Of the 3020 hunting dogs tested for $A$. reconditum, 84 were microfilaremic with an overall prevalence of $2.8 \%$. In a previous survey, Cringoli et al. (2001) reported a higher prevalence (16.5\%; $58 / 351$ ) in a no specific dog population of the same region. This discrepancy could be explained by the smaller size of the analyzed sample, the concentration of the enrolled dogs in a limited area of the Campania region (Napoli province), and the greater knowledge of the owners about the prophylaxis against ectoparasites developed in the last 20 years. Similar to our results, in a more recent survey in Molise, a small

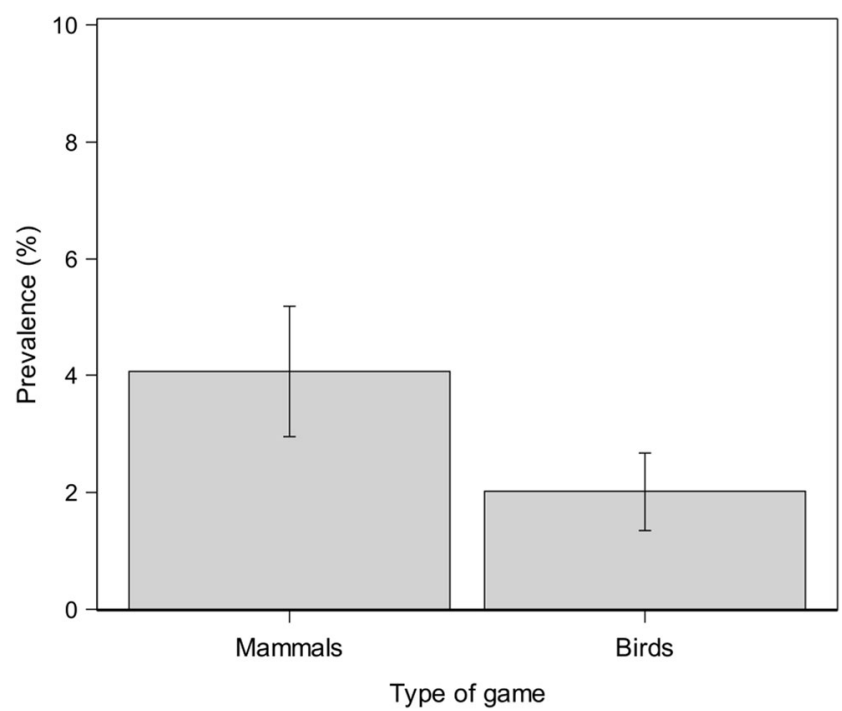

Fig. 5 Prevalence $( \pm \mathrm{SD})$ of Acanthocheilonema reconditum in hunting dogs by type of game hunted 


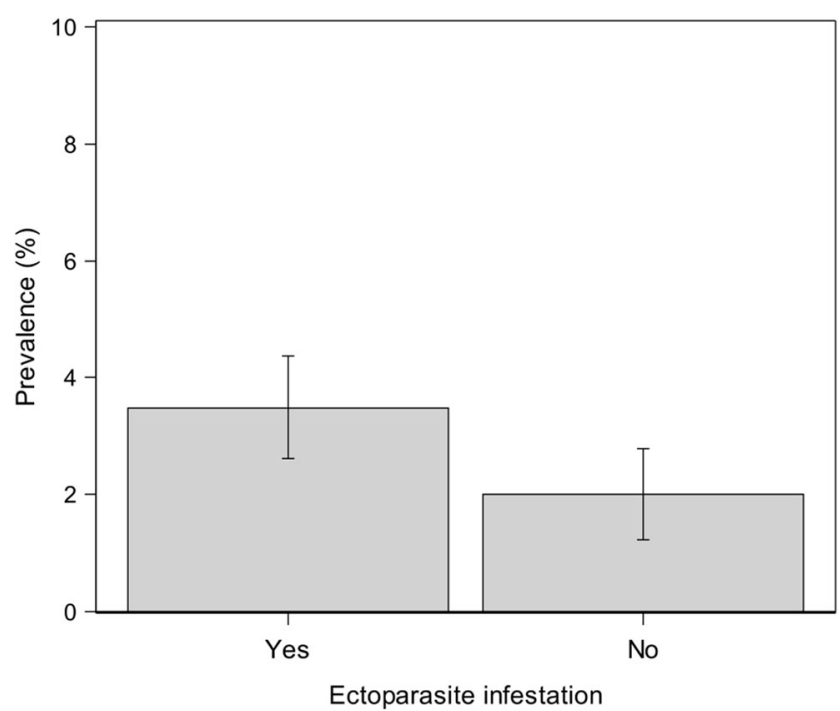

Fig. 6 Prevalence $( \pm \mathrm{SD})$ of Acanthocheilonema reconditum in hunting dogs with or without an ectoparasite infestation history

central-southern region close to our study area, Gizzarelli et al. (2019) reported an A. reconditum prevalence of $2.5 \%$ (8/318) in hunting dogs. Finally, a country-wide dog Filaridae study in Italy demonstrated a lower $A$. reconditum average prevalence of $0.8 \%$ (14/1748 dogs tested) (Brianti 2018). From the questionnaire analysis in our study, approximately $30 \%$ of hunters reported sporadic extra-label use of ivermectin. Since this macrocyclic lactone suppresses A. reconditum microfilaraemia (Lindemann and McCall 1983), it is possible that this analyzed population contained Knott's test undiagnosed cases.

It is also important to underline that to date, the distribution of $A$. reconditum could be underestimated because it is

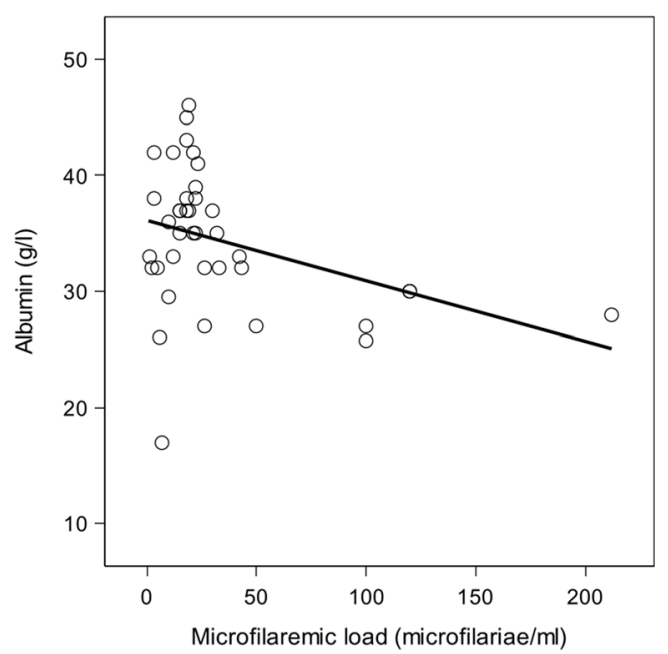

Fig. 7 Relationship between microfilaremic load and albumin serum concentration in hunting dogs showing Acanthocheilonema reconditum single infection generally identified during the search for other filarial species. Moreover, the routine use of in-clinic rapid tests for the detection of D. immitis antigens in blood samples has facilitated the diagnosis of this major filarial worm in dogs, but has likely contributed to a reduction in the opportunity to diagnose A. reconditum infections through the Knott's test that is a time-consuming procedure (Magnis et al. 2013; Evans et al. 2019). Recently, the molecular methods that allow to achieve a diagnosis at species level for $A$. reconditum have increased compared to testing modalities used in the past (Laidoudi et al. 2020a, 2020b), but as they are cannot yet be considered a routine diagnostic resource.

The history of ectoparasite infestation and hunting of wild mammals are risk factors for $A$. reconditum in hunting dogs. These findings could be explained by the close contact that occurs between wild mammals and dogs during hunting activities, which exposes the dog to the ectoparasites infesting the prey. A recent study described C. felis and C. canis as most common infestations of wildlife, highlighting that sharing habitats between mammals of different species facilitates the ectoparasite spillover (Clark et al. 2018). The spread of filariasis within wild canid populations, such as foxes, has been well documented in Europe (Hodžić et al. 2015; Ionică et al. 2017). In central Italy, the presence of A. reconditum in fox populations reported a prevalence of $10.9 \%$ (Marconcini et al. 1996) and 9.1\% (Magi et al. 2008), resulting the most common filariasis identified among investigated foxes. Furthermore, the spread of $A$. reconditum is related to its presence in confined populations, thus probably indicating that the infected animals may play a key role as reservoir (Brianti et al. 2012). In fact, the latter authors during a 2-year study reported an $A$. reconditum prevalence of $11.2 \%$ in a confined shelter dog population, with an annual incidence of $5.9 \%$. This illustrates how close contact with $A$. reconditum-infected hosts is crucial for the development of new cases, because only the adult flea stage is a competent vector for transmission. Therefore, the proximity, during hunting activities of dogs with wild animals, which are potential reservoirs of A. reconditum, could play an important epidemiological role in transmission (Diakou et al. 2016). It should also be added that dogs used for hunting mammals (mainly wild boars) are maintained in packs of at least 4-5 animals (Sgroi et al. 2020), a factor that can favour the spread of the ectoparasites among dogs reared together and thus could facilitate the transmission of $A$. reconditum.

There were significant differences between geographical areas, with higher prevalence in dogs from Caserta and Napoli provinces of Campania region. These results may be related to different dog management practices and to environmental factors as well. For instance, in Caserta province more than one microfilaremic dog belonged to the same owner and most microfilaremic dogs did not receive adequate ectoparasiticide treatment program during the year. In fact, 
the owners limited the administration of generic spot-on solutions only during the warmer period, leaving dogs exposed to ectoparasites especially during the hunting season. In Napoli province, the high presence of $A$. reconditum had been previously reported, suggesting a localized hotspot (Cringoli et al. 2001). Napoli province was indeed the highest risk, since A. reconditum prevalence was relatively high despite only a few dogs having an ectoparasite history, none of which hunted mammals, contrary to Caserta where these risk factors were well represented. It is important to underline that in Campania region the presence of suitable vectors is well documented: Rinaldi et al. (2007) described C. felis as the most common flea species infesting the dog population, even in urban areas, reporting that the climatic conditions would easily support the presence of fleas all year long.

Regarding the limited clinical, haematological, and serum biochemical findings generated for the $71 \mathrm{~A}$. reconditum-infected dogs, this parasite appears to be minimally pathogenic. Specifically, during the clinical examination, we did not observe any skin lesions (e.g. dermatitis, alopecia and nodules), as previously reported by Brianti et al. (2012). Two A. reconditum microfilaremic dogs were reported by owners to have poor performance during hunting activity. Exercise intolerance is a clinical phenomenon that is often observed in dogs during the hunting season (Hunt et al. 2018). It can be difficult to establish the cause of episodic weakness, as it can be related to several pathological conditions, including heartworm disease, which is always considered in the differential diagnosis by clinicians. Papazahariadou et al. (1994) reported a significant correlation between episodic weakness and D. immitis microfilaraemia in hunting dogs living in Greece, but this association was not confirmed by authors for A. reconditum microfilaremic dogs.

Concerning the limited haematological variables among infected dogs, our results identified leukocytosis with eosinophilia and monocytosis. These findings are consistent with data reported during the acute and chronic phase of an experimentally induced infection (Lindemann et al. 1983). Similarly, Hashem and Badawy (2007) reported leukocytosis, with neutrophilia, eosinophilia, lymphocytosis, and monocytosis in dogs naturally infected with A. reconditum. Leukocytosis, primarily involving eosinophils, monocytes, and neutrophils, can be related to the dog's immune response to cuticular microfilarial antigens (Simon and Genchi 2001).

A finding of increased serum total proteins and total globulin levels in our study population is consistent with findings reported by Hashem and Badawy (2007), and can be explained by a chronic immune response to the parasite or perhaps to other undiagnosed infections. Acanthocheilonema reconditum microfilaremic dogs in our study had no consistent indications of liver or kidney injury, as instead previously reported by Hashem and Badawy (2007).
Hypoalbuminemia has been reported in D. immitis and D. repens infections because of liver and kidney damage due to immune-pathological and mechanical activity of microfilariae (Mircean et al. 2017). Liver injury was a speculated cause for hypoalbuminemia (Hashem and Badawy 2007); however, when hypoalbuminemia occurs in natural A. reconditum infections, it is likely due to another cause. Hypoalbuminemia was not detected by Lindemann et al. (1983) in experimental A. reconditum study, despite documented proteinuria during the chronic infection phase. In the current study, there was a significant negative correlation between microfilaremic load and serum albumin level. This finding could be explained by the nutritional utilization by the microfilariae of amino acids from the bloodstream (Simon and Genchi 2001; Simón et al. 2012) or alternatively other mechanisms. Among microfilaremic dogs in this study, only a single animal was hypoalbuminemic, whereas the albumin concentrations of the other dogs, although negatively related to the parasite load, remained in the reference range, suggesting a body response to the presence of microfilariae but not a real pathological effect.

\section{Conclusions}

In conclusion, the present study further confirms the circulation of $A$. reconditum infection in southern Italy and highlights how hunting dogs represent a risk population due to their outdoor lifestyle and their close contact with wildlife. Moreover, regarding this filarial infection, further studies should be performed to better investigate epidemiological relationships between hunting dogs, wild animal populations, and the biological role of the different competent vectors sharing the same area. Finally, our data highlight that A. reconditum can be considered a minimally or nonpathogenic filarial infection in dogs. However, as some dogs may have a high microfilarial load, it is important to adhere to preventive measures against arthropod vectors to limit the infection with this filarial worm.

Acknowledgements The authors thank the following veterinaries for their cooperation: Claudio Amore, Pasquale Apicella (ASL Salerno), Salvatore Auriemma, Loredana Avallone, Gennaro Barra, Raffaele Bevilacqua, Annalisa Bianco, Gaetano Bove (ASL Salerno), Antonio Bufalo, Pasquale Buonocore, Giacomo Calabria, Angela Capozzo, Vincenzo Cardamone, Francesco Celano, Filomena Consales, Valerio Corvino, Domenico Crocetta, Cristina Cucciniello, Pompeo D'Apice, Susanna De Luca, Giovanni De Lucia, Lucio De Maria, Anna Fiorella Desiderio, Enrico Di Blasi, Carmine Diffidenti, Laura Ferraro, Antonio Fimiani, Alfonso Gallo, Saverio Giordano, Enrico Lanaro, Antonio Lepore, Francesca Lombardi, Cosimo Manna, Ivan Maraviglia, Paola Napolitano, Antonio Natale, Antonio Pacifico, Carmine Palo, Gerardo Paraggio (ASL Salerno), Agnese Parrilli, Nunzia Pelliccia, Michele Percesepe, Luca Pericolo, Gaetano Petta, Massimiliano Boris Pietraggi, Simona Pisano, Antonio Raffaele, Vincenzo Raimondi, Enrico Renzulli, 
Stanislao Ricciardi, Antonio Ricco, Giovanni Russo (ASL Salerno), Pasquale Russo, Edoardo Sanfelice di Monteforte, Giampiero Sepe, Giuseppe Sorrentino, Mario Sorrentino, Luigi Scarpato, Valerio Toscano, Alessio Vitale, Pierluigi Vitale, Antonio Zotti, and Alessandro Zullo.

Author contribution Experimental conception and design: Diego Piantedosi and Vincenzo Veneziano. Collection and analysis of samples: Laura Pacifico, Giovanni Sgroi, Benedetto Neola, and Francesco Buono. Statistical analysis: Nicola Ferrari and Claudia Romeo. Data processing and maps creation: Paolo Varuzza. Analysis and interpretation: Vincenzo Veneziano, Diego Piantedosi, Ramaswamy Chandrashekar, Melissa Beall, Laura Pacifico, Jesse Buch, and Edward B. Breitschwerdt. Paper writing: Laura Pacifico, Diego Piantedosi, Claudia Romeo, and Vincenzo Veneziano. All authors read and approved the final manuscript.

Funding Open access funding provided by Università degli Studi di Napoli Federico II within the CRUI-CARE Agreement. The study was supported by the management committees of the hunting districts of Napoli (ATC NA), Avellino (ATC AV), Salerno (ATC SA 1), Benevento (ATC BN) and Caserta (ATC CE).

Availability of data and materials The data supporting the conclusions of this article are included within the article.

\section{Declarations}

Ethics approval and consent to participate All procedures were performed for diagnostic purposes during a routine health check, and for this reason, the study did not require an ethical approval according to European Directive 2010/63/EU; a written informed consent was obtained from the owners of the dogs included in the study.

Conflict of interest The authors declare no competing interests.

Open Access This article is licensed under a Creative Commons Attribution 4.0 International License, which permits use, sharing, adaptation, distribution and reproduction in any medium or format, as long as you give appropriate credit to the original author(s) and the source, provide a link to the Creative Commons licence, and indicate if changes were made. The images or other third party material in this article are included in the article's Creative Commons licence, unless indicated otherwise in a credit line to the material. If material is not included in the article's Creative Commons licence and your intended use is not permitted by statutory regulation or exceeds the permitted use, you will need to obtain permission directly from the copyright holder. To view a copy of this licence, visit http://creativecommons.org/licenses/by/4.0/.

\section{References}

Alsarraf M, Levytska V, Mierzejewska EJ, Poliukhovych V, Rodo A, Alsarraf M, Kavalevich D, Dwużnik-Szarek D, Behnke JM, Bajer A (2021) Emerging risk of Dirofilaria spp. infection in Northeastern Europe: high prevalence of Dirofilaria repens in sled dog kennels from the Baltic countries. Sci Rep 11(1):1068

Aranda C, Panyella O, Eritja R, Castellà J (1998) Canine filariasis. Importance and transmission in the Baix Llobregat area, Barcelona (Spain). Vet Parasitol 77(4):267-275

Attipa C, Solano-Gallego L, Leutenegger CM, Papasouliotis K, Soutter F, Balzer J, Carver S, Buch JS, Tasker S (2019) Associations between clinical canine leishmaniosis and multiple vector-borne co-infections: a case-control serological study. Vet Res 15(1):331

Bain O, Beaucournu JC (1974) Larves infestantes de Dipetalonema sp. chez des puces récoltées chez des renards du sud-ouest de la France. Annales de Parasitologie 49:123-125

Brianti E (2018) Italian nationwide survey on filariosis and angiostrongilosis. Proceedings of 6th European Dirofilaria and Angiostrongylus Days Belgrade, Serbia. July 5 - 7. Parasit Vectors 11(Suppl 1):623

Brianti E, Gaglio G, Napoli E, Giannetto S, Dantas-Torres F, Bain O, Otranto D (2012) New insights into the ecology and biology of Acanthocheilonema reconditum (Grassi, 1889) causing canine subcutaneous filariosis. Parasitology 139(4):530-536

Bucklar H, Scheu U, Mossi R, Deplazes P (1998) Breitet sich in der Südschweiz die Dirofilariose beim Hund aus? [Is dirofilariasis in dogs spreading in south Switzerland?]. Schweiz Arch Tierheilkd 140(6):255-260

BURC (2019) Bollettino Ufficiale Regione Campania n. 35, 20 Giugno 2019 Calendario per l'annata venatoria 2019-2020. http://burc. regione.campania.it

Capelli G, Genchi C, Baneth G, Bourdeau P, Brianti E, Cardoso L, Danesi P, Fuehrer HP, Giannelli A, Ionică AM, Maia C, Modrý D, Montarsi F, Krücken J, Papadopoulos E, Petrić D, Pfeffer M, Savić S, Otranto D, Poppert S, Silaghi C (2018) Recent advances on Dirofilaria repens in dogs and humans in Europe. Parasit Vectors 11:663

Chabaud AG, Bain O (1994) The evolutionary expansion of the Spirurida. Int J Parasitol 24:1179-1201

Chauve CM (1990) Dirofilaria repens (Railliet and Henry, 1911), Dipetalonema reconditum (Grassi, 1890), Dipetalonema dracunculoides (Cobbold, 1870) et Dipetalonema grassii (Noè, 1907): quatre filaires méconnues du chien. Prat Med Chir Anim 25:293-304

Clark NJ, Seddon JM, Šlapeta J, Wells K (2018) Parasite spread at the domestic animal - wildlife interface: anthropogenic habitat use, phylogeny and body mass drive risk of cat and dog flea (Ctenocephalides spp.) infestation in wild mammals. Parasit Vectors 11(1):8

Cringoli G, Rinaldi L, Veneziano V, Capelli G (2001) A prevalence survey and risk analysis of filariosis in dogs from the Mt. Vesuvius area of southern Italy. Vet Parasitol 102(3):243-252

Dantas-Torres F, Otranto D (2020) Overview on Dirofilaria immitis in the Americas, with notes on other filarial worms infecting dogs. Vet Parasitol 282:109113

De Bosschere H, Kindermans E (2019) Accidental diagnosis of Dirofilaria repens in a hematoma in a dog in Belgium. [abstract]. Vlaams Diergeneeskundig Tijdschrift 88(1):39-43

Deplazes P, Guscetti F, Wunderlin E, Bucklar H, Skaggs J, Wolff K (1995) Endoparasite infection in stray and abandoned dogs in southern Switzerland. Schweiz Arch Tierheilkd 137(5):172-179 Article in German

Diakou A, Kapantaidakis E, Tamvakis A, Giannakis V, Strus N (2016) Dirofilaria infections in dogs in different areas of Greece. Parasit Vectors 9:508

Duchos de Lahitte JD (1990) Epidémiologie des filarioses en France. Prat Méd Chir Anim Cie 25(3):293-304

Duscher G, Feiler A, Wille-Piazzai W, Bakonyi T, Leschnik M, Miterpáková M, Kolodziejek J, Nowotny N, Joachim A (2009) Nachweis von Dirofilarien in österreichischen Hunden [Detection of Dirofilaria in Austrian dogs]. Berl Munch Tierarztl Wochenschr 122(5-6):199-203

Engelmann AM, Schafer AS, Lhamas CL, Dornelles GL, Cargnelutti JF, Ramos RAN, Monteiro SG, Andrade CM (2019) Morphological and molecular identification of Acanthocheilonema reconditum in a canine. Comp Clin Pathol 28:271-274 
Evans CC, Bradner JL, Savadelis MD, Nelson CT, Moorhead AR (2019) Acetic acid as an alternative reagent in the modified Knott test. Vet Parasitol 276:108975

Farkas R, Mag V, Gyurkovszky M, Takács N, Vörös K, Solymosi N (2020) The current situation of canine dirofilariosis in Hungary. Parasitol Res 119(1):129-135

Ferreira C, Afonso A, Calado M, Maurício I, Alho AM, Meireles J, Madeira de Carvalho L, Belo S (2017) Molecular characterization of Dirofilaria spp. circulating in Portugal. Parasit Vectors 10(1):250

Founta A, Theodoridis Y, Frydas S, Chliounakis S (1999) The presence of filarial parasites of dogs in Serrae Province. J Hell Vet Med Soc 50:315-320 (Article in Greek)

Genchi C, Kramer LH (2020) The prevalence of Dirofilaria immitis and D. repens in the Old World. Vet Parasitol 280:108995

Genchi M, Traldi G, Genchi C (2010) Manuale di Parassitologia Veterinaria, 1st edn. Casa Editrice Ambrosiana, Milano

Georgieva D, Kirkova Z, Ivanov A (2001) A study on the incidence and diagnostics of dirofilariosis (heartworm disease) in carnivores. Bulg J Vet Med 4:231-236

Giannetto S, Poglayen G, Gaglio G, Brianti E (2007) Prevalence and epidemiological aspects of microfilaraemia in dogs in Sicily. Abstract book of the 1st European Dirofilaria days Zagreb, Croatia.

Gizzarelli M, Foglia Manzillo V, Ciuca L, Morgoglione ME, El Houda Ben Fayala N, Cringoli G, Oliva G, Rinaldi L, Maurelli MP (2019) Simultaneous detection of parasitic vector borne diseases: a robust cross-sectional survey in hunting, stray and sheep dogs in a Mediterranean area. Front Vet Sci 6:288

Grassi B, Calandruccio S (1890) Ueber Haematozoon Lewis. Entwicklungcyclus einer Filaria (Filaria recondita Grassi) des Hundes. Centralbl Bacter Parasitenk 7:18-26

Guven E, Avcioglu H, Cengiz S, Hayirli A (2017) Vector-Borne Pathogens in Stray Dogs in Northeastern Turkey. Vector Borne Zoonotic Dis 17(8):610-617

Hamel D, Silaghi C, Lescai D, Pfister K (2012) Epidemiological aspects on vector-borne infections in stray and pet dogs from Romania and Hungary with focus on Babesia spp. Parasitol Res 110(4):15371545

Hashem M, Badawy A (2007) Hematological and biochemical studies on filariasis of dogs. Internet J Veterin Med 4(2)

Hinaidy HK, Bacowsky H, Hinterdorfer F (1987) Importation of the dog filariae Dirofilaria immitis and Dipetalonema reconditum into Austria. Zentralbl Veterinarmed 34:326-332

Hodžić A, Alić A, Fuehrer HP, Harl J, Wille-Piazzai W, Duscher GG (2015) A molecular survey of vector-borne pathogens in red foxes (Vulpes vulpes) from Bosnia and Herzegovina. Parasit Vectors 8:88

Holler D, Racz A, Bošnir J, Petrak O (2010) The prevalence of dirofilariasis in the hinterland of the Istrian peninsula. Med Jad 40(3-4):67-74

Hunt H, Cave NJ, Gartrell BD, Cogger N, Petersen J, Roe WD (2018) An epidemiological investigation of an idiopathic myopathy in hunting dogs in New Zealand. N Z Vet J 66(4):199-204

Ionică AM, Matei IA, Mircean V, Dumitrache MO, D'Amico G, Győrke A, Pantchev N, Annoscia G, Albrechtová K, Otranto D, Modrý D, Mihalca AD (2015) Current surveys on the prevalence and distribution of Dirofilaria spp. and Acanthocheilonema reconditum infections in dogs in Romania. Parasitol Res 114(3):975-982

Ionică AM, Matei IA, D'Amico G, Ababii J, Daskalaki AA, Sándor AD, Enache DV, Gherman CM, Mihalca AD (2017) Filarioid infections in wild carnivores: a multispecies survey in Romania. Parasit Vectors 10(1):332

Jacobs DE, Prole JHB (1976) Helminth infections of British dogs: prevalence in racing greyhounds. Vet Parasitol 1:377-387

Kartashev V, Batashova I, Kartashov S, Ermakov A, Mironova A, Kuleshova Y, Ilyasov B, Kolodiy I, Klyuchnikov A, Ryabikina E, Babicheva M, Levchenko Y, Pavlova R, Pantchev N, Morchón R, Simón F (2011) Canine and human dirofilariosis in the rostov region (southern Russia). Vet Med Int 2011:685713-685715. https://doi. org/10.4061/2011/685713

Kirkova Z, Ivanov A, Georgieva D (2007) Dirofilariosis in dogs and wild carnivores in Bulgaria. Free comunication in 1st European Dirofilaria days Zagreb, Croatia February 22-25.

Kokkinos P, Dimzas D, Pantchev N, Tamvakis A, Balzer J, Diakou A (2019) Filarial infections in dogs in Cyprus, an apparently heartworm free island. Vet Parasitol Reg Stud Reports 18:100330

Korkejian A, Edeson JF (1978) Studies on naturally occurring filarial infections in dogs in Lebanon. I. Dipetalonema reconditum. Ann Trop Med Parasitol 72:65-78

Laflamme DP (1997) Development and validation of a body condition score system for dogs. Canine Pract 22:10-15

Laidoudi Y, Ringot D, Watier-Grillot S, Davoust B, Mediannikov O (2019) A cardiac and subcutaneous canine dirofilariosis outbreak in a kennel in central France. Un foyer de dirofilariose canine cardiaque et sous-cutanée dans un chenil du centre de la France. Parasite 26:72

Laidoudi Y, Davoust B, Varloud M, Niang EHA, Fenollar F, Mediannikov O (2020a) Development of a multiplex qPCR-based approach for the diagnosis of Dirofilaria immitis, D. repens and Acanthocheilonema reconditum. Parasit Vectors 13(1):319

Laidoudi Y, Bedjaoui S, Medkour H, Latrofa MS, Mekroud A, Bitam I, Davoust B, Otranto D, Mediannikov O (2020b) Molecular approach for the diagnosis of blood and skin canine filarioids. Microorganisms. 8(11):1671

Leschnik M, Löwenstein M, Edelhofer R, Kirtz G (2008) Imported nonendemic, arthropod-borne and parasitic infectious diseases in Austrian dogs. Wien Klin Wochenschr 120:59-62

Liesner JM, Krücken J, Schaper R, Pachnicke S, Kohn B, Müller E, Schulze C, von Samson-Himmelstjerna G (2016) Vector-borne pathogens in dogs and red foxes from the federal state of Brandenburg, Germany. Vet Parasitol 224:44-51

Lindemann BA, McCall JW (1983) Microfilaricidal activity of ivermectin against Dipetalonema reconditum. J Vet Pharmacol Ther 6(1): $75-76$

Lindemann BA, Evans TL, Mc Call JW (1983) Clinical responses of dogs to experimentally induced Dipetalonema reconditum infection. Am J Vet Res 44:2170-2173

Macchioni F, Sed G, Cecchi F (2020) Canine filarial infections in an area of Central Italy (Tuscany-Latium border) historically free from the disease. Vet Parasitol Reg Stud Reports 20:100404

Magi M, Calderini P, Gabrielli S, Dell'Omodarme M, Macchioni F, Prati MC, Cancrini G (2008) Vulpes vulpes: a possible wild reservoir for zoonotic filariae. Vector-borne Zoonot Dis 8:249-252

Magi M, Guardone L, Prati MC, Tozzini G, Torracca B, Monni G, Macchioni F (2012) Canine filarial infections in Tuscany, central Italy. J Helminthol 86:113-116

Magi M, Guardone L, Mignone W, Monni G, Tozzini G, Prati MC, Macchioni F (2016) Canine filarial infections in Liguria, northwest Italy. J Helminthol 90:121-124

Magnis J, Lorentz S, Guardone L, Grimm F, Magi M, Naucke TJ, Deplazes P (2013) Morphometric analyses of canine blood microfilariae isolated by the Knott's test enables Dirofilaria immitis and D. repens species-specific and Acanthocheilonema (syn. Dipetalonema) genus-specific diagnosis. Parasit Vectors 6:48

Maia C, Altet L, Serrano L, Cristóvão JM, Tabar MD, Francino O, Cardoso L, Campino L, Roura X (2016) Molecular detection of Leishmania infantum, filariae and Wolbachia spp. in dogs from southern Portugal. Parasit Vectors 9(1):170

Marconcini A, Magi M, Macchioni G, Sassetti M (1996) Filariosis in foxes in Italy. Vet Res Commun 20(4):316-319

Martins Pereira N, Madeira de Carvalho LM, Pereira de Fonseca IM, Jesus Correia JM, Ferreira de Silva JM, Fazendeiro MI (2004) Uncommon and ectopic localization of adult form of 
Acanthocheilonema reconditum at the large ligament and left ventricle of the dog. Acta Parasitol Port 11:1-2

Masny A, Lewin T, Salamatin R, Golab E (2011) The first report on detection of canine Acanthocheilonema reconditum in Poland and the associated diagnostic problems. Pol J Vet Sci 14(3):485-487

McCall JW, Genchi C, Kramer LH, Guerrero J, Venco L (2008) Heartworm disease in animals and humans. Adv Parasitol 66:193285

Mendoza-Roldan J, Benelli G, Panarese R, Iatta R, Furlanello T, Beugnet F, Zatelli A, Otranto D (2020) Leishmania infantum and Dirofilaria immitis infections in Italy, 2009-2019: changing distribution patterns. Parasit Vectors 13(1):193

Menn B, Lorentz S, Naucke TJ (2010) Imported and travelling dogs as carriers of canine vector-borne pathogens in Germany. Parasit Vectors 3:34

Meyer HP, Wolvekamp P, van Maanen C, Stokhof AA (1994) Seven cases of heartworm disease (dirofilariosis) in dogs in the Netherlands. Vet Quarterly 16(3):169-174

Mircean M, Ionică AM, Mircean V, Györke A, Codea AR, Tăbăran FA, Taulescu M, Dumitrache MO (2017) Clinical and pathological effects of Dirofilaria repens and Dirofilaria immitis in a dog with a natural co-infection. Parasitol Int 66:331-334

Miterpáková M, Antolová D, Hurníková Z, Dubinský P, Pavlacka A, Németh J (2010) Dirofilaria infections in working dogs in Slovakia. J Helminthol 84(2):173-176

Morchón R, Carretón E, González-Miguel J, Mellado-Hernández I (2012) Heartworm disease (Dirofilaria immitis) and their vectors in Europe - new distribution trends. Front Physiol 3:196

Muñoz-Caro T, Conejeros I, Zhou E, Pikhovych A, Gärtner U, Hermosilla C, Kulke D, Taubert A (2018) Dirofilaria immitis microfilariae and third-stage larvae induce canine NETosis resulting in different types of neutrophil extracellular traps. Front Immunol 9: 968

Napoli E, Brianti E, Falsone L, Gaglio G, Foit S, Abramo F, Annoscia G, Dantas-Torres F, Giannetto S, Otranto D (2014) Development of Acanthocheilonema reconditum (Spirurida, Onchocercidae) in the cat flea Ctenocephalides felis (Siphonaptera, Pulicidae). Parasitology 141(13):1718-1725

Nelson GS (1962) Dipetalonema reconditum (Grassi, 1889) from the dog with a note on its development in the flea, Ctenocephalides felis and the louse, Heterodoxus spiniger. J Helminthol 36:297-308

Newton WL, Wright WH (1956) The occurence of the dog filariid other than Dirofilaria immitis in the United States. Int J Parasitol 42:246 258

Noë G (1907) La Filaria grassii n. sp., e la Filaria recondita Grassi. Acc dei Lincei 16:806-810

Orr B, Ma G, Koh WL, Malik R, Norris JM, Westman ME, Wigney D, Brown G, Ward MP, Šlapeta J (2020) Pig-hunting dogs are an atrisk population for canine heartworm (Dirofilaria immitis) infection in eastern Australia. Parasit Vectors 13(1):69

Ortega-Mora LM, Gomez-Bautista M, Rojo-Vazquez F, Rodenas A, Guerrero J (1991) A survey of the prevalence of canine filariosis in Spain. Prev Vet Med 11:63-68

Otranto D, Brianti E, Dantas-Torres F, Miró G, Latrofa MS, Mutafchiev Y, Bain O (2012) Species diversity of dermal microfilariae of the genus Cercopithifilaria infesting dogs in the Mediterranean region. Parasitology 140(1):99-108

Otranto D, Dantas-Torres F, Brianti E, Traversa D, Petri D, Genchi C, Capelli G (2013) Vector-borne helminthes of dogs and humans in Europe. Parasit Vectors 6:16

Otranto D, Iatta R, Baneth G, Cavalera MA, Bianco A, Parisi A, DantasTorres F, Colella V, McMillan-Cole AC, Chomel B (2019) High prevalence of vector-borne pathogens in domestic and wild carnivores in Iraq. Acta Trop 197:105058

Overgaauw P, van Dijk E (2009) Autochthonous case of Dirofilaria repens in a dog in the Netherlands. Vet Rec 164(5):158
Panarese R, Iatta R, Latrofa MS, Zatelli A, Ćupina AI, Montarsi F, Pombi M, Mendoza-Roldan JA, Beugnet F, Otranto D (2020) Hyperendemic dirofilaria immitis infection in a sheltered dog population: an expanding threat in the Mediterranean region. Int J Parasitol 50(8):555-559

Pantchev N, Etzold M, Daugschies A, Dyachenko V (2011) Diagnosis of imported canine filarial infections in Germany 2008 - 2010. Parasitol Res 9:S61-S76

Papazahariadou MG, Koutinas AF, Rallis TS, Haralabidis ST (1994) Prevalence of microfilaraemia in episodic weakness and clinically normal dogs belonging to hunting breeds. J Helminthol 68:243-245

Perez-Sanchez R, Gomez-Bautista M, Enginas Grandes A (1989) Canine filariasis in Salamanca (northwest Spain). Ann Trop Med Parasitol 83(2): $143-150$

Petruschke G, Rossi L, Genchi C, Pollono F (2001) Canine dirofilariasis in the canton of Ticino and in the neighboring areas of northern Italy. Schweiz Arch Tierheilkd 143:141-147

Piantedosi D, Neola B, D'Alessio N, Di Prisco F, Santoro M, Pacifico L, Sgroi G, Auletta L, Buch J, Chandrashekar R, Breitschwerdt EB, Veneziano V (2017) Seroprevalence and risk factors associated with Ehrlichia canis, Anaplasma spp., Borrelia burgdorferi sensu lato, and D. immitis in hunting dogs from southern Italy. Parasitol Res 116(10):2651-2660

Potkonjak A, Rojas A, Gutiérrez R, Nachum-Biala Y, Kleinerman G, Savić S, Polaček V, Pušić I, Harrus S, Baneth G (2020) Molecular survey of Dirofilaria species in stray dogs, red foxes and golden jackals from Vojvodina, Serbia. Comp Immunol Microbiol Infect Dis 68:101409

Prosl H, Schwendenwein I, Kolm U (2003) Dirofilariosis in Austria. Helminthological Colloquium. Vienna, Austria. Abstract.

Radev V, Lalkovski N, Zhelyazkov P, Kostova T, Sabev P, Nedelchev N, Vassileva R (2016) Prevalence of gastrointestinal parasites and Dirofilaria spp. in stray dogs from some regions in Bulgaria. Bulg J Vet Med 1:57-62

Ramos RA, de Oliveira do Rêgo AG, de Farias Firmino ED, do Nascimento Ramos CA, de Carvalho GA, Dantas-Torres F, Otranto D, Alves LC (2016) Filarioids infecting dogs in northeastern Brazil. Vet Parasitol 226:26-29

Rinaldi L, Spera G, Musella V, Carbone S, Veneziano V, Iori A, Cringoli $\mathrm{G}$ (2007) A survey of fleas on dogs in southern Italy. Vet Parasitol 148(3-4):375-378

Sabūnas V, Radzijevskaja J, Sakalauskas P, Petkevičius S, Karvelienė B, Žiliukiene J, Lipatova I, Paulauskas A (2019) Dirofilaria repens in dogs and humans in Lithuania. Parasit Vectors 12(1):177

Schäfer I, Volkmann M, Beelitz P, Merle R, Müller E, Kohn B (2019) Retrospective evaluation of vector-borne infections in dogs imported from the Mediterranean region and southeastern Europe (2007-2015). Parasit Vectors 12(1):30

Sgroi G, Varcasia A, D'Alessio N, Varuzza P, Buono F, Amoroso MG, Boufana B, Otranto D, Fioretti A, Veneziano V (2020) Taenia hydatigena cysticercosis in wild boar (Sus scrofa) from southern Italy: an epidemiological and molecular survey. Parasitology 24:1-7

Simon F, Genchi C (2001) Heartworm infection in humans and animal. I ed. Ediciones Universidad de Salamanca

Simón F, Siles-Lucas M, Morchón R, González-Miguel J, Mellado I, Carretón E (2012) Human and animal dirofilariasis: the emergence of a zoonotic mosaic. Clin Microbiol Rev 25:507-544

Svobodova V, Misonova P (2005) The potential risk of Dirofilaria immitis becoming established in the Czech Republic by imported dogs. Vet Parasitol 128(1-2):137-140

Svobodová Z, Svobodová V, Genchi C, Forejtek P (2006) The first report of authochthonous dirofilariosis in dogs in the Czech Republic. Helminthologia 43(4):242-245

Tahir D, Davoust B, Parola P (2019) Vector-borne nematode diseases in pets and humans in the Mediterranean Basin: An update. Vet World 12(10):1630-1643 
Tasić A, Rossi L, Tasić S, Miladinović-Tasić N, Ilić T, Dimitrijević S (2008) Survey of canine dirofilariasis in Vojvodina. Serbia. Parasitol Res 103:1297-1302

Tasić A, Tasić-Otašević S, Gabrielli S, Miladinović-Tasić N, Ignjatović A, Dorđević J, Dimitrijević S, Cancrini G (2012) Canine Dirofilaria infections in two uninvestigated areas of Serbia: epidemiological and genetic aspects. Vector Borne Zoonotic Dis 12(12):1031-1035

Thrusfield M (1995) Veterinary epidemiology. Blackwell Science

Toparlak M, Gargili A, Ulutas Esatgil M, Cetinkaya H (2005) Canine filariosis around Istanbul, Turkey employing naphtol AS-TR phosphatase. Acta Vet Brno 74:233-236

Traversa D, Morelli S, Cassini R, Crisi PE, Russi I, Grillotti E, Manzocchi S, Simonato G, Beraldo P, Viglietti A, De Tommaso C, Pezzuto C, Pampurini F, Schaper R, Frangipane di Regalbono A (2019) Occurrence of canine and feline extra-intestinal nematodes in key endemic regions of Italy. Acta Trop 193:227-235
Veneziano V (2001) Diffusione delle filarie del cane analisi della bibliografia nazionale e studio sulla prevalenza di microfilarie in cani di un'area del sud Italia. PhD Thesis, XIII Ciclo

Víchová B, Miterpáková M, Iglódyová A (2014) Molecular detection of co-infections with Anaplasma phagocytophilum and/or Babesia canis canis in Dirofilaria-positive dogs from Slovakia. Vet Parasitol 203(1-2):167-172

Yildirim A, Ica A, Atalay O, Duzlu O, Inci A (2007) Prevalence and epidemiological aspects of Dirofilaria immitis in dogs from Kayseri Province, Turkey. Res Vet Sci 82(3):358-363

Zahler M, Glaser B, Gothe R (1997) Imported parasites in dogs: Dirofilaria repens and Dipetalonema reconditum. Tierarztl Prax 25(4):388-392

Publisher's note Springer Nature remains neutral with regard to jurisdictional claims in published maps and institutional affiliations. 